\title{
High QUALITY Finishing OF BEVEL GEARS BY ELECTROCHEMICAL HONING
}

\author{
SHAIKH, J. H. \& JAIN, N.K.
}

Abstract: This chapter presents the development of an innovative experimental setup for finishing the bevel gears by Electro-chemical honing (ECH) process and experimental investigations on the effects of electrolyte composition and finishing time on surface roughness of straight bevel gears with an objective to improve their overall surface quality. A novel concept of using twin complementary cathode gears has been envisaged to meet the challenge of finishing the complex conical geometry of the bevel gears by ECH without providing reciprocating motion and to ensure high quality finishing of bevel gears by ECH. Average surface roughness $\left(R_{a}\right)$ and maximum surface roughness $\left(R_{\max }\right)$ have been considered to evaluate the effects of the chosen input parameters. The experiments were designed and conducted using full factorial approach of experimental design. The experimental results have shown significant improvement in surface finish of the bevel gears. The analysis of finished surface through SEM images has shown improvement in the surface integrity of the workpiece gears. This work establishes ECH a productive and economical alternative finishing process for the bevel gears giving high quality surface finish.

Key words: ECH, Bevel Gears, High Quality Finishing, Surface Roughness
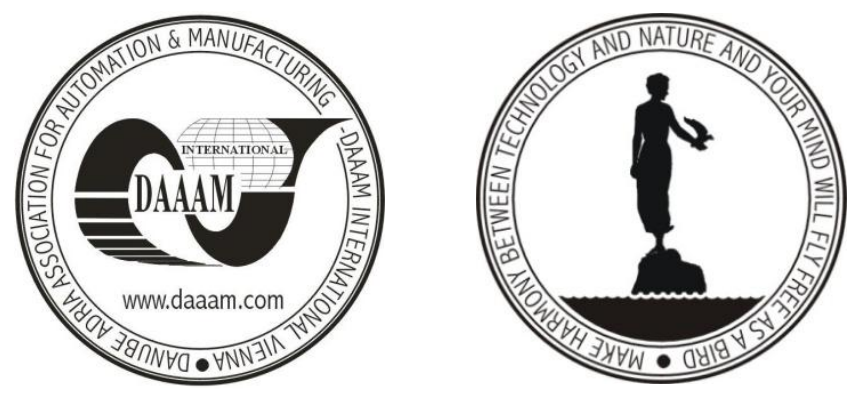

Authors' data: Shaikh, J[aved] H[abib]; Jain, N[eelesh] K[umar]*, Discipline of Mechanical Engineering, Indian Institute of Technology Indore, 453 446, MP, INDIA, shaikhjaved1@gmail.com, nkjain@iiti.ac.in

This Publication has to be referred as: Shaikh, J[aved] H[abib] \& Jain, N[eelesh] K[umar] (2013) High Quality Finishing of Bevel Gears by Electrochemical Honing, Chapter 41 in DAAAM International Scientific Book 2013, pp. 697-710, B. Katalinic \& Z. Tekic (Eds.), Published by DAAAM International, ISBN 978-3-901509-94-0, ISSN 1726-9687, Vienna, Austria

DOI: 10.2507/daaam.scibook.2013.41 
Shaikh, J. H. \& Jain, N.K.: High Quality Finishing of Bevel Gears by Electrochemi...

\section{Introduction}

Bevel gears are used to transmit motion and/or power between two intersecting shafts. They are mainly used in automobiles, aerospace and marine applications, machine tools, process industry equipments, construction equipments, etc. The operating performance, service life, transmission efficiency, and noise and vibration characteristics of these gears depends on surface finish and accuracy of the gear tooth. Usually more than one finishing operations are required after manufacturing of gear, in order to achieve the required surface finish and geometric accuracy. Improving surface finish of the gear tooth helps in preventing different modes of gear failure such as micro-pitting, pitting, adhesive wear, abrasive wear and scuffing (Davis, 2005). The two conventional bevel gear finishing processes are gear grinding and gear lapping. But, both these processes suffer from some inherent limitations. Gear grinding is a complicated and expensive process. Moreover, it can cause undesirable effects such as transverse grind lines which affect the noise and vibration characteristics of the gears and grinding burns which damage the surface integrity of the ground gears (Karpuschewski et al., 2008). Gear lapping is very slow operation and it can correct only minute deviations from the desired gear tooth profiles. Due to longer finishing time, this process does not have any control over the geometric accuracy. Moreover, the members of the lapped gear pair cannot be interchanged with the members of any other similar pair (Karpuschewski et al., 2008). Electrolytic dissolution based finishing processes can overcome most of these limitations due to their unique capabilities such as finishing performance being independent of material hardness, better surface finish without any mechanical and thermal damage and higher productivity as mentioned by Rajurkar et al. (1999).

Electrochemical honing $(\mathrm{ECH})$ is a hybrid finishing process combining capabilities of electrochemical machining (ECM) to give faster material removal rate (MRR) and stress-free surfaces and capabilities of mechanical honing to correct geometric errors and give controlled functional surface, in a single operation. At the same time, ECH also overcomes their individual limitations. It has many advantages over the conventional gear finishing processes such as its applicability regardless of material hardness, high material removal rate, better surface finish, better geometric accuracy and absence of tool wear.

\section{Review of Past Work}

Capello and Bertoglio (1979) were probably the first researchers to use ECH for finishing the hardened helical gear of involute profile. They used a specially designed cathodic helical gear tool, $\mathrm{NaNO}_{3}$ as electrolyte, inter-electrode gap (IEG) of $0.4 \mathrm{~mm}$, and voltage in the range of $10-15 \mathrm{~V}$. Their results were not acceptable in terms of the helix angle and involute profiles of the finished gear. Chen et al. (1981) developed ECH setup for high accuracy finishing of spur gears and reported an improvement in the accuracy of profile as well as in the surface finish of the spur gear teeth and reduction in noise level. Yi et al. (2000) used ECM-based process for tooth profile-modification of carburized hypoid gears and investigated current density distribution in the gear teeth. They reported that both the current and processing periods affect the volume of crown and the amount of modification. Yi et al. (2002) 
used electrochemical tooth-profile modification process on real-time control basis and used artificial neural network for its mathematical modeling. Naik et al. (2008) investigated on finishing of spur gears by $\mathrm{ECH}$ and reported percentage improvement up to $80 \%$ and $67 \%$ in average surface roughness $\left(R_{a}\right)$ and maximum surface roughness $\left(R_{t m}\right)$ respectively. Misra et al. (2010) used ECH for finishing the helical gears made of EN8 and investigated the effects of voltage, electrolyte concentration and rotary speed of the workpiece gear on surface finish using an aqueous solution of $\mathrm{NaCl}$ and $\mathrm{NaNO}_{3}$ in a ratio of 3:1 as electrolyte. They reported that electrolyte concentration and voltage have more significant effects on ECH process performance than the rotary speed. Ning et al. (2011) used pulse electrochemical finishing (PECF) for the spiral bevel gears in which only one gear tooth was finished at a time. They used a cathode cutter which rotates and passes through the tooth space of the workpiece gear. After reaching the full depth, the cutter withdraws and the gear is indexed for the finishing of the next tooth. They reported the improvements in surface roughness and geometric accuracy. They also developed a mathematical model for total thickness of the material removed and surface roughness produced, and validated it with the experimental results. Misra et al. (2012) used pulsed-ECH (PECH) for finishing the spur gears and studied the effects of composition and temperature of electrolyte on the surface finish. They also found a ratio of 3:1 of $\mathrm{NaCl}$ and $\mathrm{NaNO}_{3}$ as optimum electrolyte composition and $30^{\circ} \mathrm{C}$ as optimum electrolyte temperature.

\section{Research Objectives and Methodology}

From the review of the past work it is evident that as of now no research has been reported on development of ECH for finishing the straight bevel gears. The present work bridges this gap through development of the $\mathrm{ECH}$ process for improving surface finish and surface integrity of the straight bevel gears and experimental investigations on the process performance. Following were the objectives indentified on the basis of the review of the past work:

1. To conceptualize the arrangement of workpiece, cathode and honing gears so as to finish the complex conical geometry of the bevel gears by ECH process.

2. To design and fabricate an experimental setup based on the conceived working principle for finishing the bevel gears by $\mathrm{ECH}$.

3. To study the effects of ECH process parameters on the surface finish, geometric accuracy and MRR of the finished gears through systematic planning and designing of the experiments and thorough analysis of the experimental results.

4. To study the changes in surface characteristics as surface integrity, bearing area curve and microstructure of the gears finished by ECH.

5. To study the mechanism of material removal and the contribution of mechanical honing and ECM in MRR and surface roughness generation.

6. To develop theoretical models of material removal rate (MRR) and surface roughness and validate them experimentally. The theoretical models will have wide applicability than the empirical or semi-empirical models.

7. Multi-objective optimization of the $\mathrm{ECH}$ process parameters considering the conflicting objectives such as MRR, surface roughness, and geometric accuracy. 
Shaikh, J. H. \& Jain, N.K.: High Quality Finishing of Bevel Gears by Electrochemi...

The use of optimum ECH parameters will optimize the process performance with high productivity.

Following research methodology was adopted to meet the above-mentioned research objectives. A novel concept of using twin complementary cathode gears was conceived to (i) ensure finish of the entire face width of the bevel gear teeth with reciprocating motion as required in the finishing of the cylindrical gears by $\mathrm{ECH}$, and (ii) ensure the inter electrode gap (IEG) between the workpiece and cathode gears so that short-circuiting between them is avoided. An innovative experimental setup was designed and developed based on this concept for high-quality finishing of the bevel gears by ECH. The most commonly used material in production of commercial bevel gears namely $20 \mathrm{MnCr} 5$ alloy steel was chosen as the workpiece material. An aqueous mixture of $\mathrm{NaCl}$ and $\mathrm{NaNO}_{3}$ was used as the electrolyte. Experimental investigations were conducted in the four different stages namely: (i) trial experiments, (ii) pilot experiments, (iii) main experiments, and (iv) confirmation experiments. Table 1 presents the summary of objectives, details of fixed and variable ECH parameters, measures of process performance or responses, and methodology of design of experiments for each stage of the experimental investigations. The approach for the design of experiments for each stage was decided keeping in view its objectives, number of variable parameters involved and their levels, and the constraints on the experimental resources.

Four trial experiments were conducted using full factorial approach to check the working of the setup and for initial bracketing of operating ranges for the ECH parameters for the pilot experiments. Twelve pilot experiments were conducted to fix the electrolyte composition and finishing time for the main experiments by studying their effects on the surface finish and geometric accuracy. The effects of electrolyte composition and finishing time on enhancing the geometry accuracy are reported by Shaikh \& Jain (2013a). Haisch et al. (2001) have reported that the choice of electrolyte strongly influences the surface finish produced in the electrochemical dissolution based processes. Therefore, this chapter reports about the effects of the electrolyte composition and finishing time on the surface finish and microstructure of bevel gears. The analysis has shown strong influence of electrolyte composition and finishing time on process performance. The experimental results have shown significant percentage improvement in the surface finish.

The main experiments were designed and performed according to $L_{27}\left(3^{13}\right)$ orthogonal array of Taguchi's experimental design using fixed and variable parameters as mentioned in Table 1. In these experiments five ECH parameters namely concentration, temperature and flow rate of the electrolyte, voltage applied across IEG, and rotary speed of the workpiece gear. were varied at three levels each to study their effects on the average and maximum surface roughness $\left(R_{a}\right.$ and $\left.R_{\max }\right)$ values and MRR. Shaikh et al. (2013) have reported the investigations on $R_{a}$ and $R_{\max }$. Theoretical models for MRR and surface roughness for ECH were developed based on the proposed mechanism of material removal by Shaikh \& Jain (2013b). Confirmation experiments were conducted to validate the theoretical models and results of multi-objective optimization. 
Composition (by \% Wt.) of the workpiece material (i.e. 20MnCr5 alloy steel):

Cr (0.8-1.1); Mn (1-1.3); C (0.14-0.19); P (0.035 max.); S (0.035 max.); Si (0.15-0.40); and balance Fe.

\begin{tabular}{|c|c|c|c|c|}
\hline $\begin{array}{l}\text { Stage of } \\
\text { experi- } \\
\text { mentation }\end{array}$ & Objectives & Process parameters & Responses & \begin{tabular}{|l|} 
Approach for \\
DOE and no. of \\
experiments
\end{tabular} \\
\hline Trial & $\begin{array}{l}\text { To check the } \\
\text { working of the } \\
\text { experimental setup. } \\
\text { To decide the range } \\
\text { of the selected ECH } \\
\text { parameters for pilot } \\
\text { experiments. }\end{array}$ & $\begin{array}{l}\text { Variable parameter: } \\
\text { 1.Finishing Time: } 4 \text { levels }(2,4,6,8 \mathrm{~min} \text {.) } \\
\text { Fixed parameters: } \\
\text { 1.Electrolyte composition (E): } 75 \% \mathrm{NaNO}_{3}+25 \% \\
\mathrm{NaCl} \text {. } \\
\text { 2. Electrolyte concentration (C): } 7.5 \% \text { (by wt.) } \\
\text { 3. Electrolyte temperature (T): } 32^{\circ} \mathrm{C} \\
\text { 4. Voltage: } 24 \mathrm{~V} \\
\text { 5. Electrolyte flow rate (F): } 20 \mathrm{lpm} \\
\text { 6. Rotary speed of workpiece gear (R): } 60 \mathrm{rpm}\end{array}$ & \begin{tabular}{|l|} 
Surface quality \\
through \\
visual \\
examination
\end{tabular} & $\begin{array}{l}\text { Full factorial } \\
4 \text { Experiments }\end{array}$ \\
\hline Pilot & $\begin{array}{l}\text { To find the optimum } \\
\text { levels of ECH } \\
\text { parameters which } \\
\text { are difficult to } \\
\text { change in the main } \\
\text { experiments. }\end{array}$ & $\begin{array}{l}\text { Variable parameters: } \\
\text { 1. Electrolyte composition (E): } 4 \text { levels }(100 \% \\
\mathrm{NaNO}_{3} ; 50 \% \quad \mathrm{NaNO}_{3}+50 \% \quad \mathrm{NaCl} ; \quad 25 \% \\
\left.\mathrm{NaNO}_{3}+75 \% \mathrm{NaCl} ; 75 \% \mathrm{NaNO}_{3}+25 \% \mathrm{NaCl}\right) \\
\text { 2. Finishing time (t): } 3 \text { levels }(2 \mathrm{~min} ., 4 \mathrm{~min} ., 6 \\
\text { min.) } \\
\text { Fixed parameters: } \\
\text { 1. Electrolyte concentration (C): } 7.5 \% \text { (by wt.) } \\
\text { 2. Electrolyte temperature (T): } 32^{\circ} \mathrm{C} \\
\text { 3. Voltage (V): } 12 \mathrm{~V} \\
\text { 4. Electrolyte flow rate (F): } 20 \text { lpm } \\
\text { 5. Rotary speed of workpiece gear (R): } 60 \mathrm{rpm} \\
\text { 6. Inter electrode gap: } 1 \mathrm{~mm}\end{array}$ & $\begin{array}{l}\text { PIR } \\
P I R_{\max } \\
P I f_{u} \\
P I F_{p} \\
P I F_{r} \\
\text { Bearing area } \\
\text { curve } \\
\text { SEM micro- } \\
\text { graphs }\end{array}$ & $\begin{array}{l}\text { Full factorial } \\
12 \text { Experiments }\end{array}$ \\
\hline Main & $\begin{array}{l}\text { To study the effect } \\
\text { of variable } \\
\text { parameters and their } \\
\text { interactions on the } \\
\text { response and to } \\
\text { optimize their } \\
\text { values. }\end{array}$ & 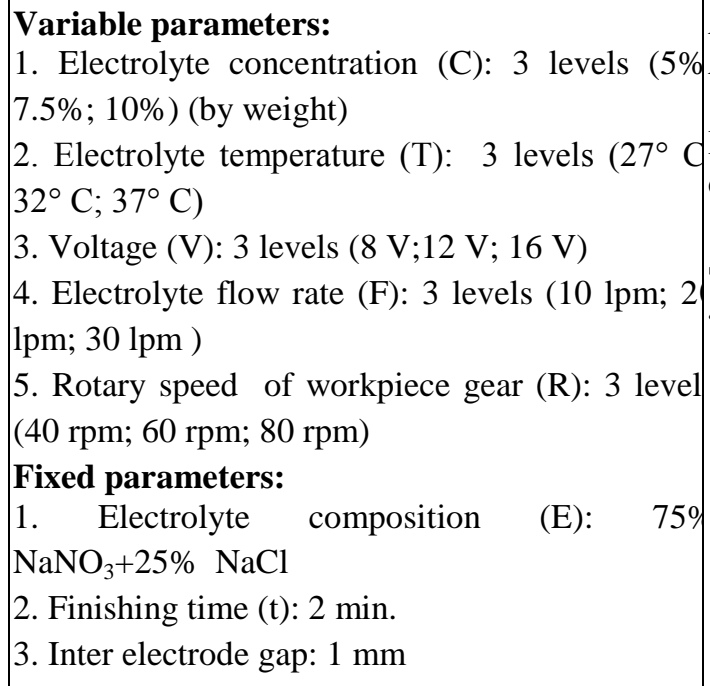 & $\begin{array}{l}P I R_{a}, \\
P I R_{\max } \\
\text { Bearing area } \\
\text { curve } \\
\text { SEM micro- } \\
\text { graphs }\end{array}$ & $\begin{array}{l}\text { Taguchi's } \\
\text { method using } L_{27} \\
\left(3^{13}\right) \text { orthogonal } \\
\text { array } \\
27 \text { Experiments }\end{array}$ \\
\hline Confirmation & $\begin{array}{l}\text { To confirm the } \\
\text { results of the main } \\
\text { experiments }\end{array}$ & Optimum parameters given by different models & $\begin{array}{l}P I R_{a} \\
P I R_{\max }\end{array}$ & 4 Experiments \\
\hline
\end{tabular}

Tab. 1. Details of objectives, fixed and variable ECH parameters, responses, and approach of design of experiments for each stage of the experimental investigations 
Shaikh, J. H. \& Jain, N.K.: High Quality Finishing of Bevel Gears by Electrochemi...

\section{Experimental Setup}

\subsection{Principle of Finishing the Bevel Gears by ECH}

Fig. 1 depicts the proposed working principle for finishing the bevel gears by $\mathrm{ECH}$. The anodic workpiece gear ' 1 ' ' is mounted on the spindle of a drilling machine. Since, for the ECM, the cathode gears have to be in constant mesh with the anodic workpiece gear therefore, to avoid the short circuiting by providing an IEG and to ensure finishing of the entire face width of bevel gear tooth, a novel concept of using twin complementary cathode gears was conceived. For this, in one of the complimentary cathode gear ' 3 ', an insulating layer of metalon is sandwiched between two conducting layers of copper while, in the other complimentary cathode gear '4', a conducting layer of copper is sandwiched between two insulating layers of metalon. Fig. 2 depicts the photographs of these complementary cathode gears. To ensure the IEG between the cathode and anode gears, the conducting layer is undercut by $1 \mathrm{~mm}$ as compared to the insulating layers. A honing gear ' 2 ' (a bevel pinion with hardness greater than that of the workpiece bevel gear) at the backside is in mesh with the workpiece gear. Both the cathode and honing gears have the same involute profile as the workpiece gears. The axes of the shafts of workpiece gear, cathode gears and honing gear are perpendicular to each other. A full stream of electrolyte ' 5 ' is supplied to the IEG, and a DC current is passed through the gap. During the electrochemical process of material removal from the tooth flank, the electrolysis action forms a metal oxide passivating layer on the tooth surface of the workpiece gear which inhibits the further material removal by ECM. This passivating layer is scraped by the honing gear. A tight meshing between the honing and the workpiece gears ensures the dual flank contact and the pressure required to remove the passivating layer. The honing gear scraps the passivating layer from the high spots. This results in relatively more material removal from the protruding high spots by the electrochemical action in the next cycle. This cyclic sequence of ECM and mechanical honing leads to improvement surface finish and surface characteristics of all the teeth of the workpiece gear simultaneously.

Based upon the above-mentioned principle, an innovative experimental setup for finishing the bevel gears by ECH was designed and developed whose schematic is shown in Fig. 3(a) and its photograph in the Fig. 3(b). This setup has four subsystems namely (i) power supply system; (ii) electrolyte supply, cleaning and recirculating system; (iii) machining chamber housing workpiece, cathode and honing gears; and (iv) A machine frame to support the machining chamber and to provide motion to the workpiece gear. The cathode gears and honing gear rotate due to meshing with the workpiece gear. A DC power supply system capable of supplying an output voltage in the range of 0-100 V, current in the range of 10-110 A and with a programmable pulse-on time and pulse-off time in the range of 5-999 $\mu$ s through space-mark controller was used. The power supply can be operated either as a constant current source or as a constant voltage source. The positive terminal of the power supply is connected to the stainless steel shaft supporting the workpiece gear while, the negative terminal is connected to two cathode gears through carbon brush and slip ring assembly. The electrolyte supply, cleaning and re-circulating system 
has been designed to supply the filtered electrolyte to the machining chamber and recirculate it back to the storage tank. A rotary pump made of stainless steel and capable of developing a wide range of pressures and flow rates was used to supply the electrolyte which is an aqueous mixture of $\mathrm{NaCl}$ and $\mathrm{NaNo}_{3}$. Filtration was achieved by using two double-staged magnetic and stainless steel mesh filters provided in the electrolyte flow path. Electrolyte pressure and flow rate measuring devices and flow control valve were employed at the pump outlet. The electrolyte temperature was maintained by a heating element fitted with a precise temperature controller. Rotary motion to the workpiece gear is provided by a DC motor fixed on the frame of a drilling machine of $38-\mathrm{mm}$ drilling capacity. This motor has a controller to vary the rotary speed continuously in the range of $30-1500 \mathrm{rpm}$. The machining chamber has been fabricated using Perspex sheets to provide better visualization of the $\mathrm{ECH}$ process and better strength-to-weight ratio

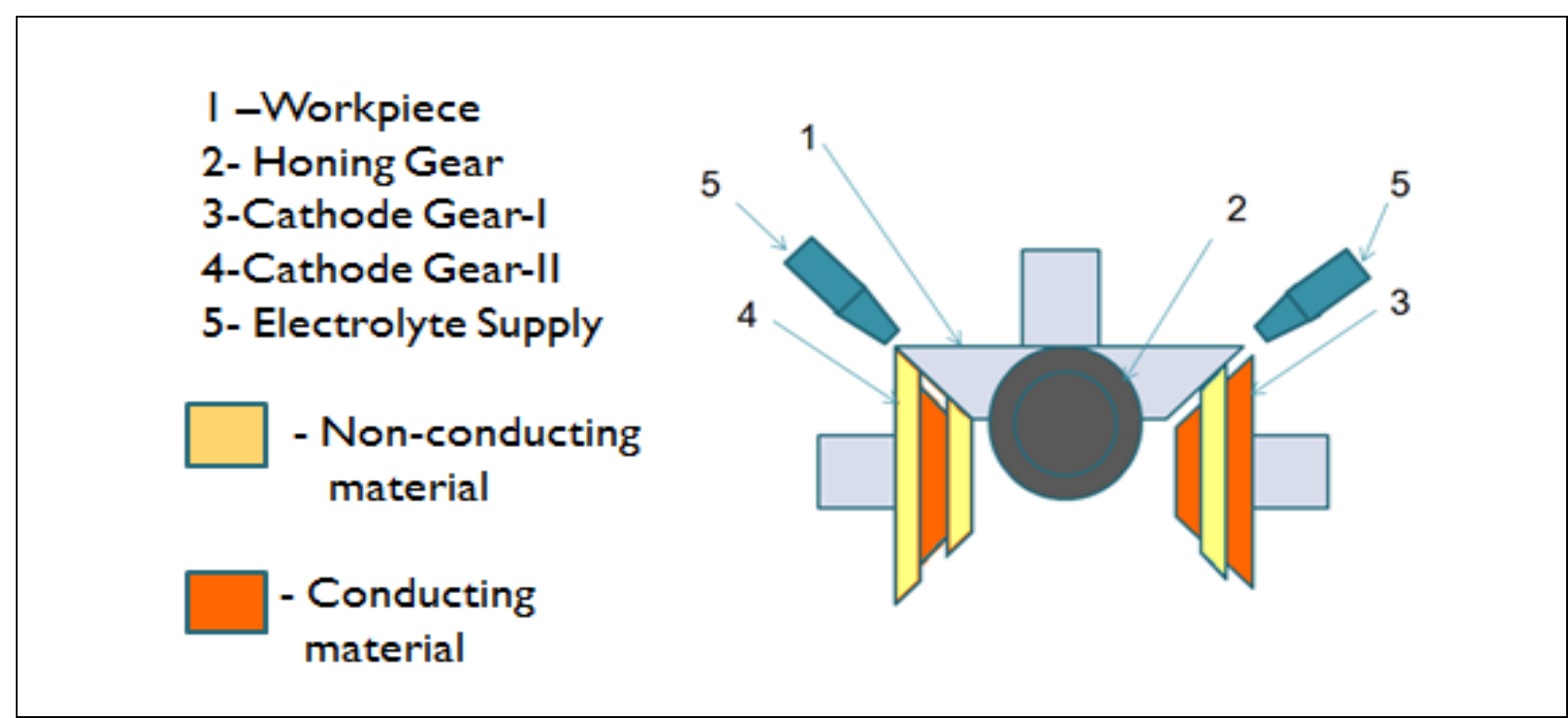

Fig. 1. Working principle of finishing the bevel gears by ECH

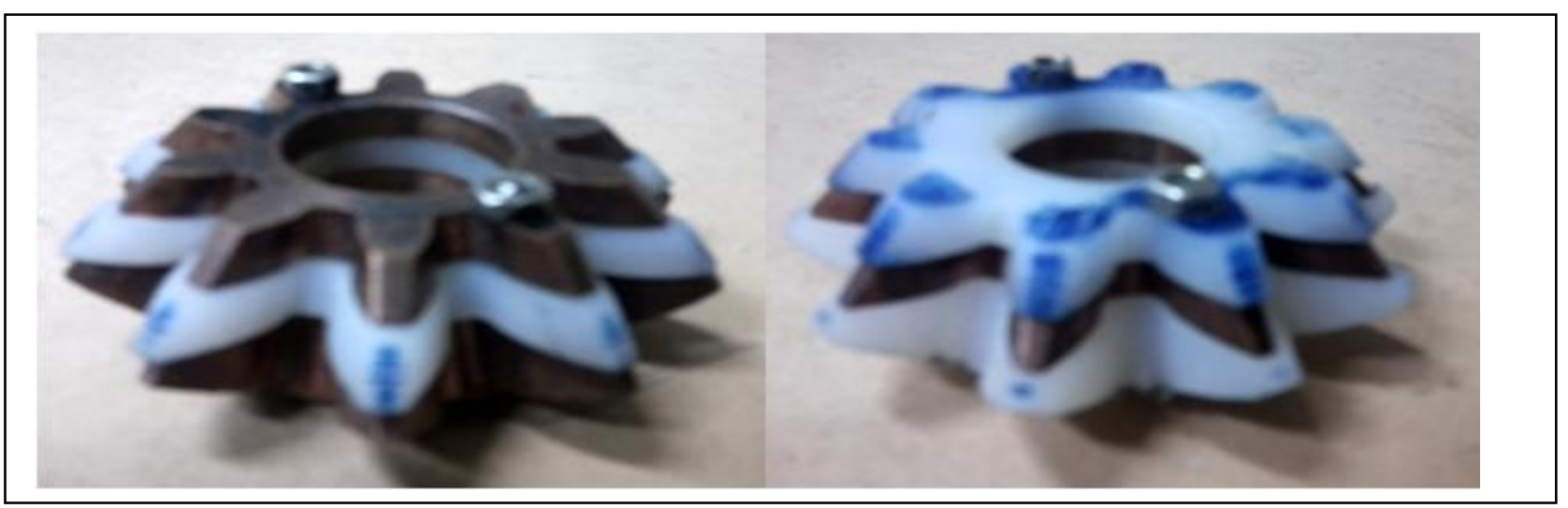

Fig. 2. Complementary cathode gears used for finishing the bevel gears by ECH

Pedestal type ball bearings were used to mount and support the stainless shafts on which honing and two cathode gears were mounted. Metalon blocks were used to support and mount the bearings due to its corrosion resistance, electrical insulation 
Shaikh, J. H. \& Jain, N.K.: High Quality Finishing of Bevel Gears by Electrochemi...

and higher strength-to-weight ratio. The table of the drilling machine having dimensions of $400 \mathrm{~mm} \times 400 \mathrm{~mm}$ was used to mount and support the machining chamber.

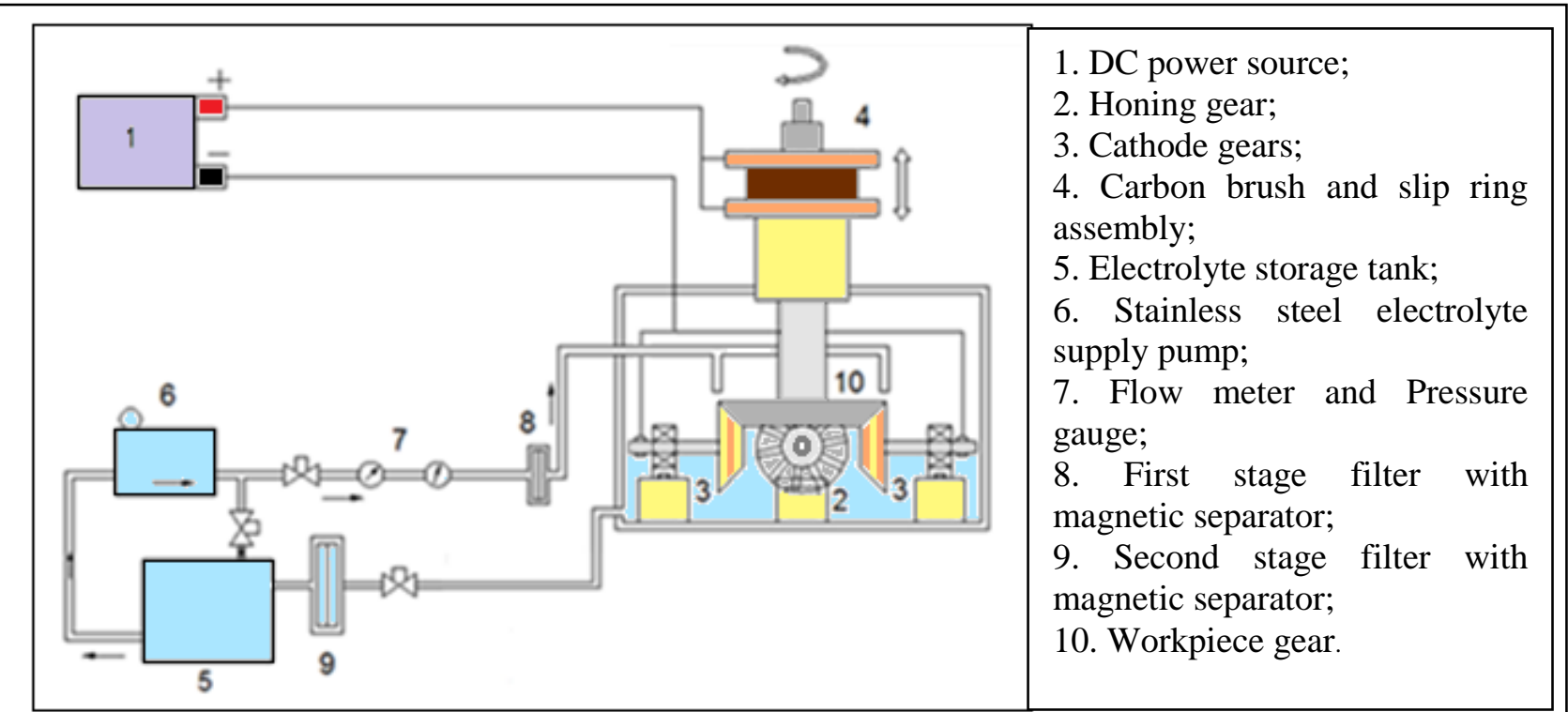

(a)

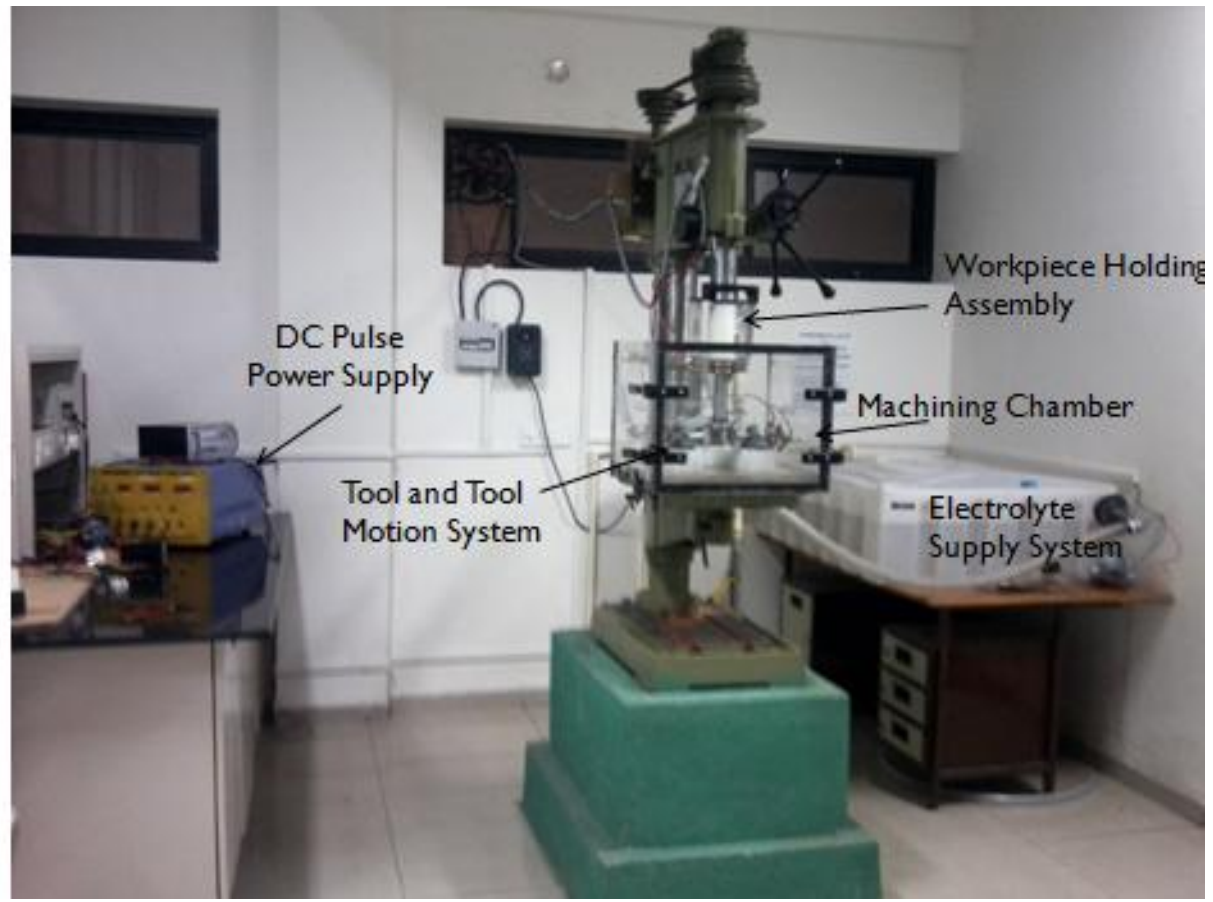

(b)

Fig. 3. Experimental setup for ECH of bevel gears: (a) schematic diagram; (b) photograph

The workpiece, cathode and honing gears were straight bevel gears having module as 4.83 . The workpiece gear was having 16 teeth while cathode and honing gears were having 10 teeth each. The workpiece bevel gears were cut on bevel gear generator based on the Gleason method in a reputed gear manufacturing company. Case hardened $20 \mathrm{MnCr} 5$ alloy steel (with the composition shown in the Table 2) 
having surface hardness in the range of 50-54 HRC was used as workpiece material because it is the most commonly used material for the production of commercial bevel gears for typical industrial applications. Honing gear was also made of the same material but of higher surface hardness (i.e. 58-62 HRC).

\section{Experimentation}

The trial experiments were performed to check the working of the developed experimental setup and to decide the operating range of the selected variable parameters. Based on these experiments, the value of the DC voltage and range of the finishing time were decided. The voltage was kept at $24 \mathrm{~V}$ and $\mathrm{ECH}$ was done for a finishing time of duration 2, 4, 6 and 8 minutes. Values of the other parameters used were electrolyte composition $\left(25 \% \mathrm{NaNo}_{3}\right.$ and $75 \% \mathrm{NaCl}$ by weight), electrolyte concentration $(7.5 \%$ by weight), electrolyte flow rate $(20 \mathrm{lpm})$, rotary speed of workpiece gear $(60 \mathrm{rpm})$ and electrolyte temperature $\left(32^{\circ} \mathrm{C}\right)$. The levels of these parameters were selected on the basis of the design constraints and review of the past work. After finishing, the surface roughness of the finished gear was checked. It was found that the higher values of the voltage and finishing time deteriorated the surface finish. Therefore, value of the DC voltage was decided to be $12 \mathrm{~V}$ and finishing time in the range of 2-6 minutes for the further experiments. The electrolyte composition was varied at 4 levels and finishing time at 3 levels to study their effects on surface finish as mentioned in the Table 2. The other ECH parameters such as voltage $(\mathrm{V})$, electrolyte concentration $(\mathrm{C})$, electrolyte temperature $(\mathrm{T})$, electrolyte flow rate $(\mathrm{F})$ and rotary speed of the workpiece gear $(\mathrm{R})$ were fixed at their central values. The 12 experiments were conducted using full factorial approach.

\begin{tabular}{|c|c|}
\hline \multirow{2}{*}{\multicolumn{2}{|c|}{$\begin{array}{l}\text { Composition (by \% Wt.) of the workpiece material (i.e. } 20 \mathrm{MnCr} 5 \text { alloy steel): } \mathrm{Cr} \\
\text { (0.8-1.1); Mn (1-1.3); C (0.14-0.19); P (0.035 max.); S (0.035 max.); Si (0.15- } \\
0.40) \text {; and balance Fe. } \\
\text { Annroach of desion of exneriments· Full Factorial Desion }\end{array}$}} \\
\hline & \\
\hline $\begin{array}{l}\text { Fixed input } \\
\text { parameters }\end{array}$ & $\begin{array}{l}\text { 1. Voltage }(\mathrm{V}): 12 \mathrm{~V} \\
\text { 2. Electrolyte concentration }(\mathrm{C}): 7.5 \% \text { (by weight) } \\
\text { 3. Electrolyte flow rate }(\mathrm{F}): 20 \mathrm{lpm} \\
\text { 4. Rotary speed of workpiece gear }(\mathrm{R}): 60 \mathrm{rpm} \\
\text { 5. Electrolyte temperature }(\mathrm{T}): 32^{\circ} \mathrm{C} \\
\text { 6. Inter electrode gap: } 1 \mathrm{~mm}\end{array}$ \\
\hline $\begin{array}{l}\text { Variable input } \\
\text { parameters }\end{array}$ & $\begin{array}{l}\text { 1. Electrolyte Composition }(\mathrm{C}): 4 \text { levels } \\
\left(100 \% \mathrm{NaNO} 3 ; 75 \% \mathrm{NaNO}_{3}+25 \% \mathrm{NaCl} ; 50 \% \mathrm{NaNO}_{3}+\right. \\
\left.50 \% \mathrm{NaCl} ; 25 \% \mathrm{NaNO}_{3}+75 \% \mathrm{NaCl}\right) \\
\text { 2. Finishing time (t): } 3 \text { levels }(2 \text { min.; } 4 \text { min.; } 6 \text { min. })\end{array}$ \\
\hline
\end{tabular}

Tab. 2. Details of the input parameters and responses used in the experimentation on finishing of the bevel gears by ECH 
Shaikh, J. H. \& Jain, N.K.: High Quality Finishing of Bevel Gears by Electrochemi...

Surface roughness was measured before and after ECH on a contracer-cumsurface roughness tester of KOSAKA make. For analysis of surface roughness parameters two gear teeth were selected. For each tooth, two measurements one on left hand profile and other on the right hand profile were performed and the average value of the concerned parameter was used to calculate the average percentage improvement in that parameter. The percentage improvement in average surface roughness ' $R_{a}$ ' values $\left(P I R_{a}\right)$ was calculated using the Eq.(1), similarly maximum surface roughness ' $R_{\max }$ ' values $\left(P I R_{\max }\right)$ were calculated. Higher values of $P I R_{a} /$ $P I R_{\max }$ indicate the smaller value of final $R_{a} / R_{\max }$.

$$
P I R_{a}=\frac{\text { Initial } R_{a} \text { value }- \text { Final } R_{a} \text { value }}{\text { Initial } R_{a} \text { value }}
$$

\section{Results and Discussion}

Fig. 4 and 5 depict the variation in the percentage improvements average surface roughness value 'PIR ${ }_{a}$ ' and maximum surface roughness value 'PIR $\max$ ' respectively with finishing time for different compositions of the electrolyte. It is clear from Fig. 4 and Fig. 5 that, increase in amount of $\mathrm{NaCl}$ causes deterioration in the surface finish. This is due to relatively more material removal rate (MRR) due to corrosive nature of $\mathrm{NaCl}$, while the combination of $50 \% \mathrm{NaNO}_{3}+50 \% \mathrm{NaCl}$ gives the highest 'PIR ${ }_{a}$ ' and 'PIR ${ }_{\max }$ ' due to the passivating nature of $\mathrm{NaNO}_{3}$. On safe side we can select $75 \% \mathrm{NaNO}_{3}+25 \% \mathrm{NaCl}$ as the optimum electrolyte composition, as it is the second candidate giving highest 'PIR ${ }_{a}$ ' and 'PIR $R_{\max }$ ' values. It is evident from the Fig. 4 and Fig. 5 that, the electrolyte composition of $75 \% \mathrm{NaNo}_{3}+25 \% \mathrm{NaCl}$ with 2 minutes finishing time yields the highest improvements in the surface finish, Hence, this combination is identified as optimum combination for the ECH of bevel gears.

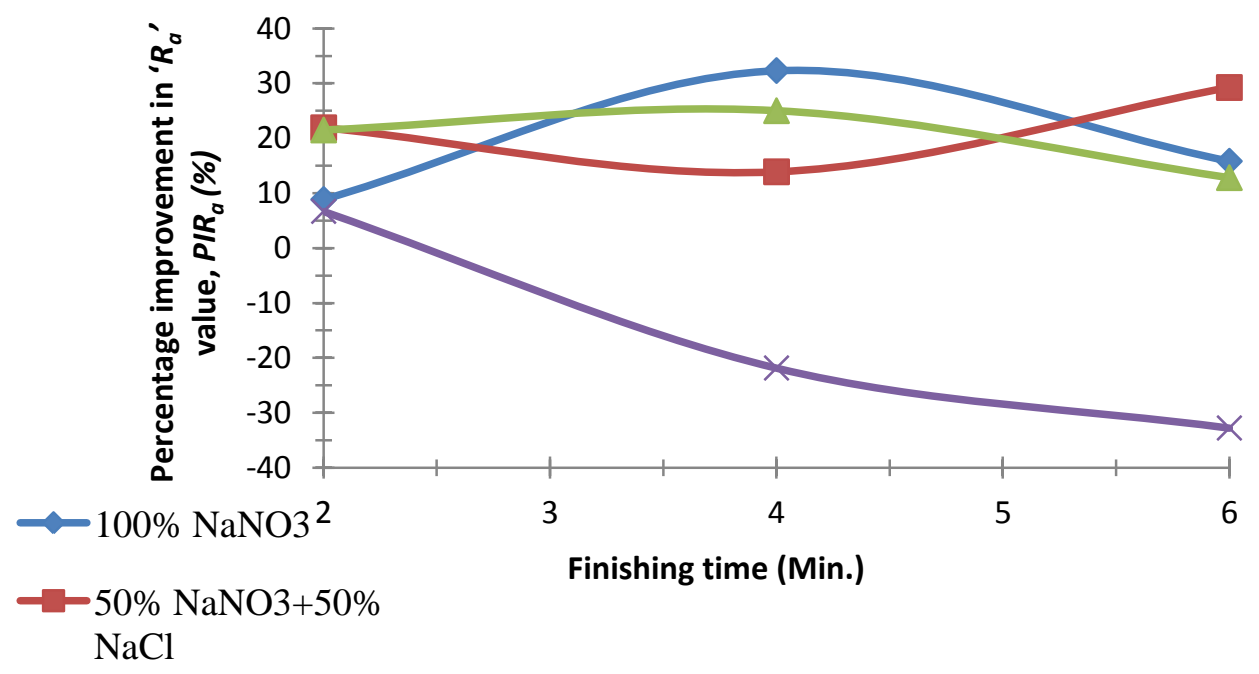

Fig. 4. Effect of electrolyte composition and finishing time on percentage improvement in average surface roughness ' $R_{a}$ ' value $\left(P I R_{a}\right)$ 


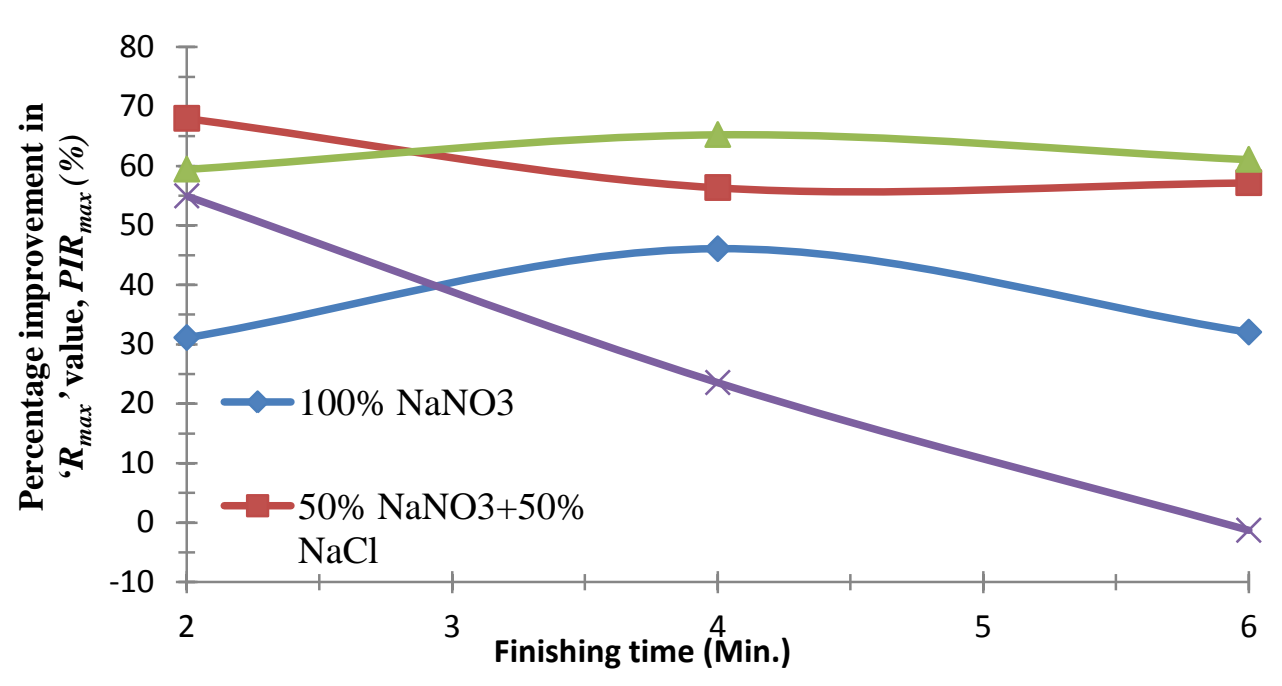

Fig. 5. Effect of electrolyte composition and finishing time on percentage improvement in maximum surface roughness ' $R_{\max }$ ' value $\left(P I R_{\max }\right)$

Figures $6(\mathrm{a})$ and $6(\mathrm{~b})$ illustrate the profile of the surface roughness before and after the ECH for the optimum parameters. It is clear from these figures that after ECH for 2 minutes the maximum surface roughness $R_{\max }$ value has improved significantly from $20.23 \mu \mathrm{m}$ to $11.4 \mu \mathrm{m}$ while, average surface roughness $R_{a}$ value has improved from $2.30 \mu \mathrm{m}$ to $1.99 \mu \mathrm{m}$.

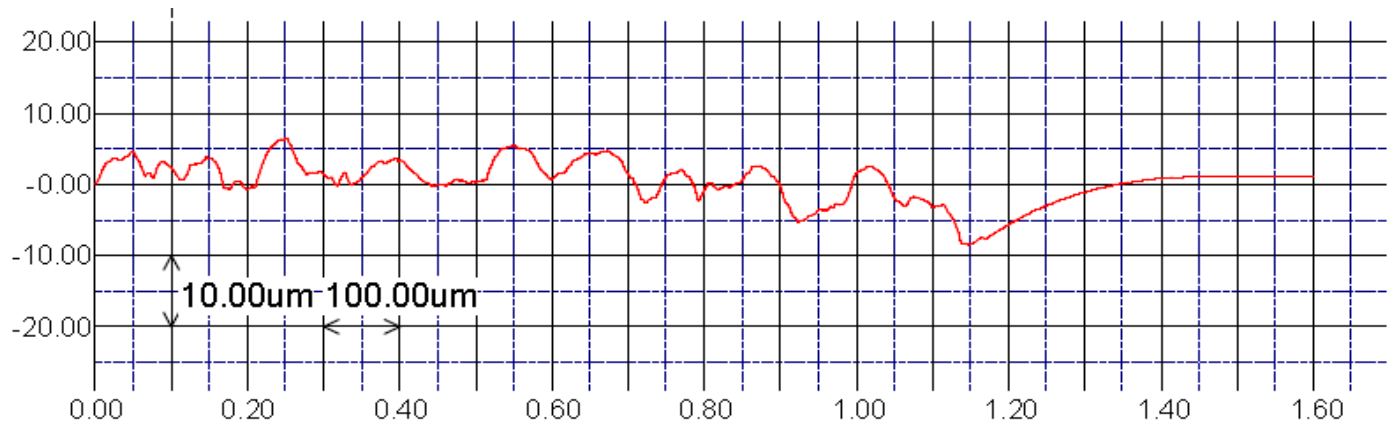

(a)

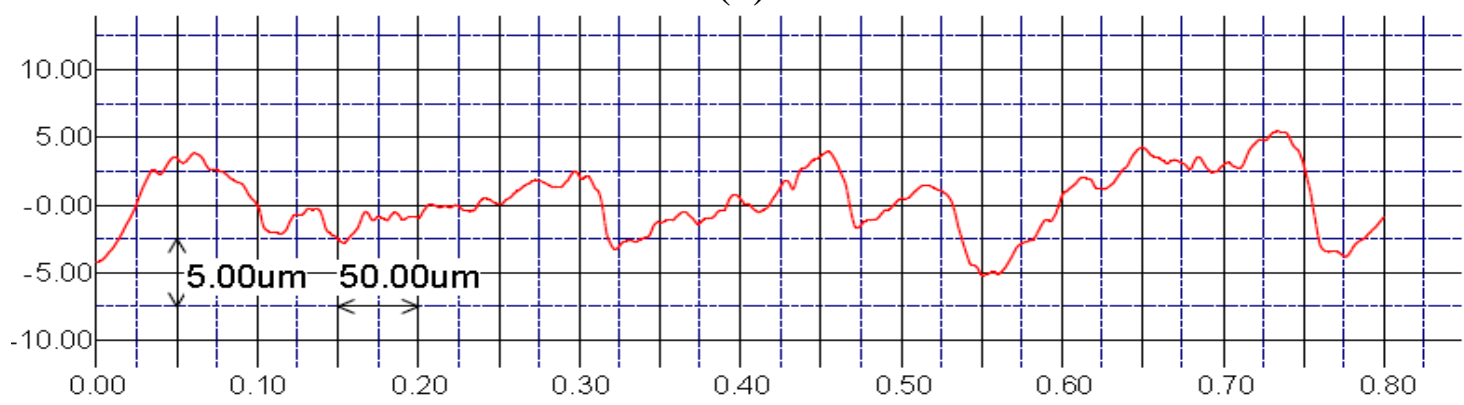

(b)

Fig. 6. Surface roughness profile of bevel gear tooth for the optimum combination of electrolyte composition and finishing time (a) before $\mathrm{ECH}\left(\mathrm{R}_{\mathrm{a}} 2.30 \mu \mathrm{m}\right.$ and $\mathrm{R}_{\max }$ $20.23 \mu \mathrm{m})$; (b) after ECH ( $\mathrm{R}_{\mathrm{a}} 1.99 \mu \mathrm{m}$ and $\left.\mathrm{R}_{\max } 11.40 \mu \mathrm{m}\right)$ 
Shaikh, J. H. \& Jain, N.K.: High Quality Finishing of Bevel Gears by Electrochemi...

Figures 7(a) and 7(b) depict the bearing area curve (BAC) for the depth of 0.5 $\mu \mathrm{m}$ before and after $\mathrm{ECH}$. The improvement in percentage material in BAC after $\mathrm{ECH}$ results in larger contact area and hence less noise and vibration during the operation and less wear.

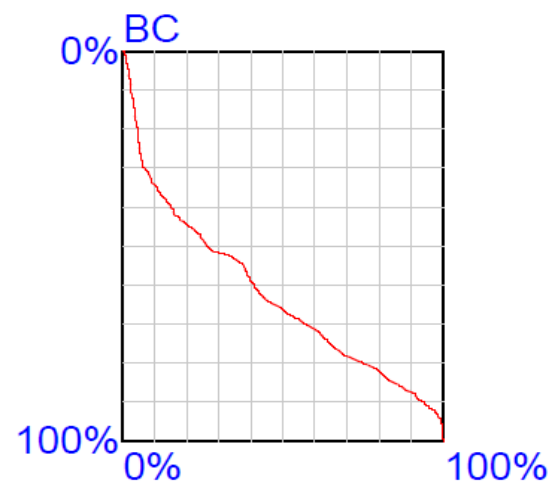

(a)

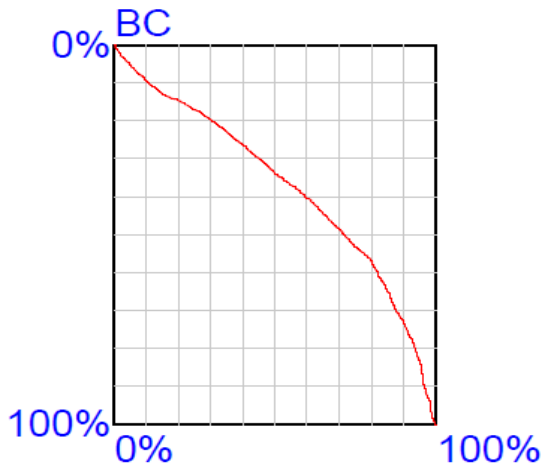

(b)

Fig. 7. Bearing area curve on the gear surface (a) before ECH; (b) after ECH

Figures 8(a) and 8(b) show the SEM micrographs for an unfinished gear and ECH finished gear respectively. From the SEM micrograph of unfinished gear the micro-pits on the tooth flank surface are clearly visible, which may lead to the fatigue failure in operating life of the gears. These pits are smoothened by the ECH as shown in Fig. 8(b).

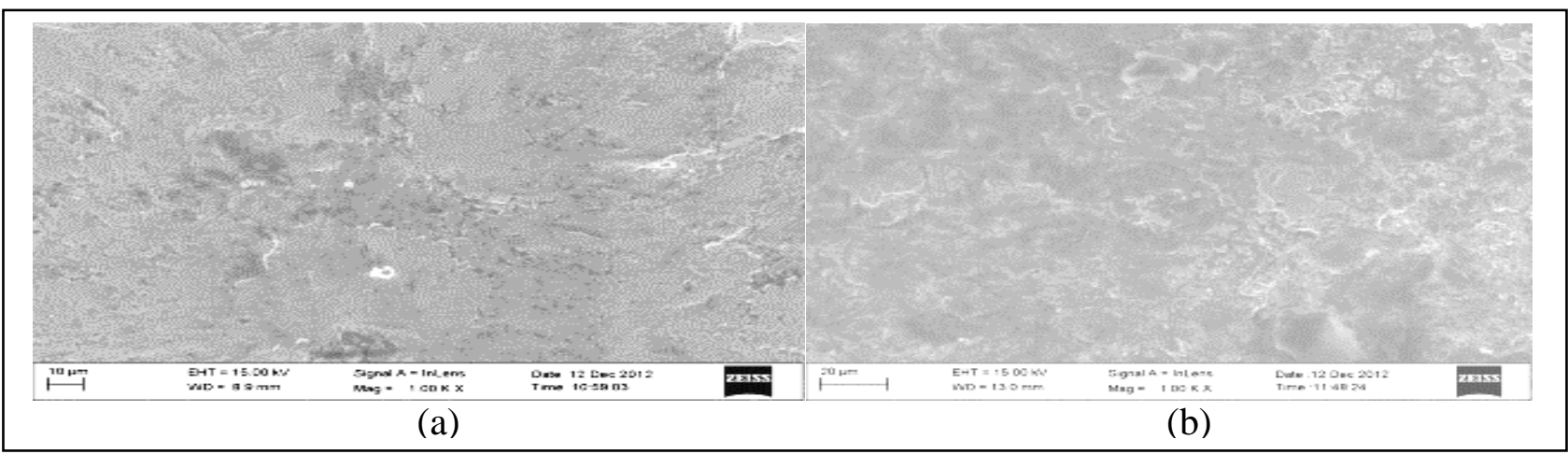

Fig. 8. Scanning electron microscopy (SEM) images for (a) unfinished gear; (b) gear finished by $\mathrm{ECH}$, for the optimum combination of electrolyte composition and finishing time

\section{Conclusion and Future Scope}

This paper reported about the experimental investigations on effect of electrolyte parameters on the enhancement of surface finish and surface characteristics of the straight bevel gears using an innovatively developed ECH setup. Following are the conclusions drawn based on this study:

1. The composition of electrolyte should be chosen very carefully. Use of more amount of corrosive electrolyte may deteriorate the surface finish.

2. ECH for longer duration deteriorates the surface finish rather than improving it. 
3. ECH significantly improves the surface integrity of the gears.

4. The study confirms ECH being an economical and highly productive alternative finishing process for the bevel gears because surface finish improved significantly within the finishing time of 2 minutes.

5. Performance of ECH is independent of the gear material hardness therefore it can improve the surface finish and surface integrity of any gear material which consequently improves the operating performance and service life of the gears.

Since, the present work is the first attempt to establish ECH as an alternative productive finishing process for the straight bevel gears therefore, there is lot of scope for the future work in this area. Following are the some future research directions:

1. Improving the geometric accuracy of bevel gears by,

$\checkmark$ Using the workpiece gears with the finishing stock, as estimated from the experimental data and/or analytical models.

$\checkmark$ Modifying the profile of the cathode gears from the analysis of simulation of meshing dynamics of gears in the ECH process.

$\checkmark$ Using cathode gears of high geometric accuracy and surface finish.

2. Automation of the ECH process using noise and vibration sensors which can stop the process whenever desired level of performance is reached.

3. Use of ECH to finish of other gears of conical geometry such as spiral bevel gears and hypoid gears using the concept of complimentary cathode gears.

4. Use of ECH for gear tooth profile modifications such as tooth profile crowing, root relief, tip relief etc. by modifying the profile of cathode gears.

5. Use of pulsed-power supply to further enhance the process performance of ECH for finishing the conical gears.

Further research is under progress at IIT Indore on all the above-mentioned aspects under the guidance of the second author of this Chapter.

\section{Acknowledgements}

The authors gratefully acknowledge (i) CSIR, New Delhi (India) for the financial support received under the Project No. 22/ (0468)/09/EMR-II, (ii) SnH Gears, Dewas, MP (India) for providing their facilities for fabrication of the bevel gears, and (iii) VE Commercial Vehicles, Pithampur, MP (India) for allowing to use their facilities for surface roughness measurements.

\section{References}

Capello, G. \& Bertoglio, S., 1979. A new approach by electrochemical finishing of hardened cylindrical gear tooth face. CIRP Annals, Vol. 28, No. 1, 103-107, ISSN: 0007-8506

Chen, C.P.; Liu, J.; Wei, G.C.; Wan, C.B. \& Wan, J. (1981). Electrochemical honing of gears: a new method of gear finishing, CIRP Annals, Vol. 30, No. 1, 103-106, ISSN: 0007-8506 
Shaikh, J. H. \& Jain, N.K.: High Quality Finishing of Bevel Gears by Electrochemi...

Davis, J.R. (2005). Gear Materials, Properties and Manufacture. ASM International, ISBN: 08717 08151, Ohio

Haisch, T.; Mittemeijer, E. \& Schultze, J.W. (2001). Electrochemical machining of the steel $100 \mathrm{Cr} 6$ in aqueous $\mathrm{NaCl}$ and $\mathrm{NaNO}_{3}$ solutions: microstructure of surface films formed by carbides, Electrochimica Acta, Vol. 47, 235-241, ISSN: 0013-4686. Karpuschewski, B.; Knoche, H.J. \& Hipke, M. (2008). Gear finishing by abrasive processes. CIRP Annals, Vol. 57, No. 2, 621-640, ISSN: 0007-8506

Misra, J.P.; Jain, N.K. \& Jain, P.K. (2010). Investigations on precision finishing of helical gears by electrochemical honing process. Proceedings of IMechE, Part B: Journal of Engineering Manufacture, Vol. 224, No. 12, 1817-1830, ISSN: 20412975

Misra, J.P.; Jain, P.K., Jain, N.K. \& Singh, H. (2012). Effects of electrolyte composition and temperature on precision finishing of spur gears by pulse electrochemical honing (PECH). International Journal of Precision Technology, Vol.3, No.1, 37-50, ISSN: 1755-2079

Naik, L. R.; Jain, N. K. \& Sharma, A. K. (2008). Investigation on precision finishing of spur gears by electrochemical honing, Proceedings of the $2^{\text {nd }}$ International and $23^{\text {rd }}$ AIMTDR Conference, IIT Madras, India, 509-514

Ning M.; Wenji X.; Xuyue W. \& Zefei W. (2011). Mathematical modeling for finishing tooth surfaces of spiral bevel gears using pulse electrochemical dissolution, International Journal of Advanced Manufacturing Technology, Vol. 54, 979-986, ISSN: 1433-3015

Rajurkar, K.P.; Zhu, D., McGeough, J.A., Kozak, J., DeSilva, A. (1999). New developments in electro-chemical machining. CIRP Annals, Vol. 48, No. 2, 567-579, ISSN: 0007-8506

Shaikh, J.H. \& Jain, N.K. (2013b). Modeling of material removal rate and surface roughness in electrochemical honing of bevel gears. Journal of Materials Processing Technology (DOI: 10.1016/j.jmatprotec.2013.08.010) ISSN: 0924-0136

Shaikh, J.H. \& Jain, N.K., (2013a). Enhancement of geometric accuracy and surface finish of bevel gears by electrochemical honing process. International Journal of Advanced Manufacturing Technology ( $4^{\text {th }}$ revised version, Manuscript ID: JAMT-D12-10950R4), ISSN: 1433-3015

Shaikh, J.H.; Jain, N.K. \& Venkatesh, V.C. (2013). "Precision Finishing of Bevel Gears by Electrochemical Honing" Materials and Manufacturing Processes. (DOI: 10.1080/10426914.2013.811737), ISSN: 1532-2475

Yi, J.; Yang, T. \& and Zhou, J. (2000). New electrochemical process gear toothprofile modification, Manufacturing Technology and Modern Machine, Vol. 9, No.1, $102-105$

Yi, J.; Zheng, J.; Yang, T.; Xia, D. \& Hu, D. (2002). Solving the control problem for electrochemical gear tooth-profile modification using an artificial neural network, International Journal of Advanced Manufacturing Technology, Vol. 19, No. 1, 8-13, ISSN: 1433-3015 